\title{
Spirituality and religiosity related to socio-demographic data of the elderly population*
}

\author{
Espiritualidade e religiosidade relacionadas aos dados sociodemográficos de idosos
}

Leiner Resende Rodrigues ${ }^{1}$, Isabella Danielle Nader ${ }^{1}$, Ana Teresa de Melo e Silva ${ }^{1}$, Darlene Mara dos Santos Tavares $^{1}$, Luiza Maria de Assunção ${ }^{1}$, Nayara Paula Fernandes Martins Molina ${ }^{1}$

Objective: to describe the relationship of spirituality and religiosity with gender, age and family income of the elderly people. Methods: this is a cross-sectional study with 643 elderly people using a socio-demographic questionnaire and a brief multidimensional measure of religiosity/spirituality. A descriptive analysis, Student's t-test (sex) and Pearson correlation for age and Spearman for income $(\mathrm{p}<0.05)$ were performed. Results: female prevailed, age group 60|-70 years old, living with the partner, education level of 1|-5 years of study and income of a minimum wage. The female presented higher averages than the male in most of the dimensions of religiosity and spirituality. The age presented a weak positive correlation in the dimensions of organizational religiosity and global self-assessment; while income did not present a statistically significant correlation. Conclusion: female and older adults presented greater dimensions of religiosity and spirituality, while income did not present significant correlation.

Descriptors: Health of the Elderly; Religion; Spirituality.

Objetivo: descrever a relação da espiritualidade e religiosidade com sexo, idade e renda familiar de idosos. Métodos: estudo transversal com 643 idosos por meio de questionário sociodemográfico e Medida multidimensional breve de religiosidade/espiritualidade. Realizou-se análise descritiva, teste t-Student (sexo) e correlação de Pearson para idade e Spearman para renda $(\mathrm{p}<0,05)$. Resultados: prevaleceu o sexo feminino, faixa etária 60|-70 anos, residem com o companheiro, escolaridade de 1|-5 anos de estudo e renda de um salário mínimo. 0 sexo feminino apresentou médias superiores ao masculino na maioria das dimensões de religiosidade e espiritualidade. A idade apresentou correlação positiva fraca nas dimensões religiosidade organizacional e autoavaliação global; enquanto a renda não apresentou correlação estatisticamente significativa. Conclusão: os idosos do sexo feminino e mais velhos apresentaram maiores dimensões de religiosidade e espiritualidade, enquanto que a renda não apresentou correlação significativa.

Descritores: Saúde do Idoso; Religião; Espiritualidade.

\footnotetext{
*Extracted from the project: Falls and violence against the elderly people in Uberaba, Universidade Federal do Triângulo Mineiro, 2014.

${ }^{1}$ Universidade Federal do Triângulo Mineiro. Uberaba, MG, Brazil. 


\section{Introduction}

The growth of the elderly population is progressively increasing and it is estimated that the number of older people will quadruple by 2060 and the life of this population will exceed 80 years old, especially women. This phenomenon will especially impact the developing countries since the demographic transition started longer in the developed countries and therefore they had more time to be prepared. Also, most of these elderly people will live in nations like Brazil $^{(1)}$.

Natural aging usually offers gains and opportunities for growth, but it also provides challenges, changes, and losses ${ }^{(2)}$. Physical, psychological, cognitive, social, physiological and other changes can be identified among the changes by the increasing age. It is observed that there are some losses proportionally, such as the withdrawal from work, independence and/or autonomy, the death of relatives, friends and also, their death ${ }^{(3)}$. All this combined can result in challenges and stressful situations that negatively affect the lives of the elderly population ${ }^{(2)}$.

It is necessary that before these losses and their consequences, there are mechanisms of coping and overcoming emerging. In this scenario, religiosity and spirituality are useful tools for coping with negative and stressful events. It is possible to elucidate the protective nature that religion and spirituality have for people, especially the elderly, helping in the way they deal with adversities ${ }^{(2)}$, and also act as strategies in the search for motivation, improvement and a sense of life.

When referring to religiosity and spirituality, it is necessary to elucidate the differences that separate these two perspectives. The word religion derives from the Latin "religare" meaning to reconnect, to reestablish the connection between God and men ${ }^{(4)}$. Their meanings integrate a system of beliefs that guide the relationships of the individual with himself and with the environment in which he is inserted.

Religiosity refers to the level of intensity that an individual accompanies, trusts, and practices a religion. Thus, it can be either organizational relating to participation in the church or religious temple, or non-organizational in the sense of attending religious programs, reading the bible or religious books and praying $^{(4)}$.

Spirituality is characterized as a human inclination to pursue meaning for life through conceptions that surpass the visible. It is a broader concept that each individual defines for himself. It is also understood as a personal search to understand issues related to the meaning of life, which may or may not lead to the development of religious practices or the formation of religious communities ${ }^{(4)}$.

In the health area, the theme has been expanded, demonstrating that religiosity and spirituality have been associated with improved health and reduction of diseases ${ }^{(5-6)}$, causing changes in practitioners' lives, especially in the lives of the elderly.

This observation leads to thinking about the role of religiosity and spirituality in aging as a mechanism of sociability in a moment of life in which the solitude and fragmentation of the family nucleus are frequent. However, the perception of Religiosity and Spirituality is influenced by several factors, such as gender, age, and income. A study carried out in a community with adults and the elderly identified a higher prevalence of female in religious practices as well as their association with older age $\mathrm{e}^{(7)}$.

This research has the purpose of contributing to broadening the knowledge about the subject, considering the limited literature that contemplates it in the scope of Collective Health. The scientific approach is still more directed to research in the psychiatry and mental health area, with nursing more focused on qualitative studies ${ }^{(5,8)}$. Therefore, the need for other investigations is reinforced, especially in Collective Health, since it has been increasingly relevant in the Brazilian social reality.

Understanding the elderly individual, within the religious and spiritual context in which he lives is fundamental so health professionals can demonstrate 
respect to the needs presented by them and reflect on the attitudes and actions they provide in the Everyday situations that can influence the natural and individual process of aging especially those professionals of Collective Health.

In this context, the study aimed to describe the relationship of spirituality and religiosity with gender, age and family income of the elderly people.

\section{Methods}

This is a cross-sectional study through a household survey, carried out from January to June 2014, in the urban area of a Minas Gerais municipality.

The population of the urban area was recruited using multi-stage conglomerate sampling. For the calculation of the sample size, a prevalence of functional disability in the $28.8 \%$ Daily Instrumental Activities was used, with a precision of $1.5 \%$ and a $95.0 \%$ confidence interval for a finite population of 199,172 (Total number of urban elderly people in the Triângulo Mineiro). However, for this research, the domains of Religiosity and Spirituality were used as outcomes. Admitting the estimated population of older adults $(36,703)$ of the municipality, a sample of 711 was reached.

There were 18 denials, 13 discontinuations, three sectors without elderly but with residence (12 elderly), four sectors without a home (16 elderly) and sectors that did not complete the number of elderly people (nine elderly people) from 711 older adults who were approached and invited to participate in the research.

The sample consisted of individuals who met the following inclusion criteria: age equal or greater than 60 years old; being resident in the urban area and without cognitive decline. The elderly people who were not located by the interviewer after three attempts; sectors without elderly; sectors without houses; and sectors that did not complete the number of elderly were excluded from the research. In this way, 643 elderly people were interviewed.
The data were collected in the elderly's residence by trained interviewers (undergraduate and postdoctoral students in the health area). Systematic meetings were held between the researcher responsible and the field supervisors for training, follow-up, and guidance.

The Mini Mental State Examination instrument validated in Brazil for the cognitive evaluation of the elderly was used, with a score of 0 to 30 points and a cut grade according to the education level of the older adults $^{(9)}$.

For the characterization of socio-demographic data, a questionnaire was prepared by the Research Group on Public Health, created in 2005, and the variables were adjusted by a pilot test. The study variables were gender (male and female); age group, in years old (60|-70.70|-80, 80 years old and over); marital state (never married, living with partner, widowed, separated); years of education (no education, $1 \vdash 5$, $5 \vdash 9$; 9 or more); and individual income, in minimum wages (without income; $<1 ; 1 ; 1|3 ; 3| 5 ;>5$ ).

Regarding the evaluation of religiosity and spirituality, the instrument of Brief Multidimensional Measure of Religiosity/Spirituality was used, validated in the Brazilian version ${ }^{(10)}$. This instrument has 38 items divided into 11 dimensions, which are: Daily Spiritual Experiences, Values/Beliefs, Forgiveness, Particular Religious Practices, Religious Outreach, Religious Support, Religious/Spiritual History, Commitment, Organizational Religiosity, Religious Preferences, and Overall Religious Self-Assessment/Spirituality. Response options are arranged on a Likert scale for eight dimensions, ranging from 1 to 8 , from 1 to 6 , or from 1 to 4 response options.

The instrument has three additional items without composing a quantitative score as in the other dimensions. They are: "Religious/spiritual history" (yes or no); "Compromise" (consisting of three questions, the first one about lifelong beliefs with response options: I totally agree, agree, disagree and totally disagree.) The second question was about the financial contribution categorized as weekly, monthly, and 
yearly. The third question was related to a number of hours devoted to religious and spiritual practice rated at 0 hours, 1 or 2 hours, 3 or 4 hours and more than 5 hours; and "Religious preference" (Catholic, Evangelical, Spiritist and non-religious).

The review and coding of the interviews were performed during the collection. In May and June of 2014, a spreadsheet was built in the Excel® program, so the data collected were processed in a microcomputer. In turn, this procedure occurred in the double entry by two researchers (postgraduate students in the health area) for subsequent verification of inconsistent data. Subsequently, the spreadsheet for the Statistical Package for Social Sciences 22.0 was imported for analysis.

The categorical variables (gender, age, marital status, education, and income) and three dimensions of religiosity and spirituality (Religious/Spiritual History, Commitment, and Religious Preference) were presented using absolute frequency distribution and percentages. The Student's t-test was used to compare the scores of the eight dimensions of Religiosity and Spirituality with the gender variable for the homogeneous variances, as well as the Welch's correction for the heterogeneous variances. For the analysis of the relationship between age and income with Religiosity and Spirituality, the correlation coefficient Pearson's product moment was used (quantitative) for age and Spearman's (ordinal) was used for income.

It is noteworthy that all prerequisites for the use of parametric tests, such as normality, atypical values, and heteroscedasticity were observed. This study considered the level of significance $\alpha=0.05$.

The study complied with the formal requirements contained in the national and international regulatory standards for research involving human beings.

\section{Results}

There was a predominance of females (66.6\%), aged between 60 and 70 years old (42.1\%), who lived with the partner (42.7\%), education for $1 \vdash 5$ years
(45.1\%) and income from an individual monthly minimum wage (45.0\%).

Regarding religiosity and spirituality, in the religious/spiritual history dimension, $46.0 \%$ of the elderly reported having had a religious or spiritual experience that changed their lives, while $70.5 \%$ of the elderly reported having some reward with their faith. Only $7.5 \%$ reported having already a significant loss of faith.

Regarding the commitment dimension, the highest percentage of the elderly people (62.4\%) reported that they fully agree to continue their religious beliefs throughout their lives. In the same dimension, the elderly (46.0\%) reported monthly contributions to the religious community they belong to, $73.9 \%$ reported not actively participating followed by $12.8 \%$ who reported participating one or two hours per week.

Regarding the religious preference dimension, the highest percentage of elderly people (69.5\%) reported being Catholic, followed by evangelicals (14.0\%).

Table 1 shows the averages of the religiosity and spirituality dimensions of the community's elderly according to gender.

Table 1 - Mean of Religious and Spirituality dimensions among community elderly population, according to gender

\begin{tabular}{|c|c|c|c|c|c|}
\hline \multirow{3}{*}{$\begin{array}{l}\text { Dimensions of religiosity } \\
\text { and spirituality }\end{array}$} & \multicolumn{4}{|c|}{ Gender } & \multirow{3}{*}{$\mathbf{p}$} \\
\hline & \multicolumn{2}{|c|}{ Male } & \multicolumn{2}{|c|}{ Female } & \\
\hline & Average & $\begin{array}{l}\text { Standard } \\
\text { Deviation }\end{array}$ & Average & $\begin{array}{l}\text { Standard } \\
\text { Deviation }\end{array}$ & \\
\hline Daily spiritual experiences & 29.72 & 4.995 & 31.18 & 3.652 & $<0.001^{\mathrm{a}}$ \\
\hline Values / beliefs & 6.95 & 1.149 & 7.16 & 0.956 & $0.024^{\mathrm{b}}$ \\
\hline Forgiveness & 10.63 & 1.931 & 11.04 & 1.462 & $0.007^{b}$ \\
\hline Particular religious practices & 21.70 & 6.771 & 25.95 & 5.157 & $<0.001^{\text {b }}$ \\
\hline Religious Overcoming & 25.14 & 3.141 & 26.18 & 2.363 & $<0.001^{\mathrm{a}}$ \\
\hline Religious support & 10.41 & 2.997 & 11.59 & 2.894 & $<0.001^{\mathrm{a}}$ \\
\hline Organizational religiosity & 4.60 & 2.623 & 5.98 & 2.985 & $<0.001^{\text {b }}$ \\
\hline $\begin{array}{l}\text { Global Self-Assessment of } \\
\text { Religious/Spirituality }\end{array}$ & 6.42 & 1.326 & 6.96 & 1.111 & $<0.001^{\text {b }}$ \\
\hline
\end{tabular}


Significant differences were observed between groups for most of the dimensions of Religiousness/ Spirituality. The female had statistically higher averages than men in the following dimensions: daily spiritual experiences; Values/beliefs; Forgiveness; Particular religious practices; Religious overcoming; Religious support; Organizational religiosity and global self-assessment of religiosity/spirituality.

Table 2 shows the correlations of the dimensions of Religious and Spirituality of the elderly in the community with the variables age and income.

Table 2 - Correlation of the Religious and Spirituality dimensions of the elderly according to age and income

\begin{tabular}{|c|c|c|c|c|}
\hline \multirow{2}{*}{$\begin{array}{l}\text { Dimensions of religiosity and } \\
\text { spirituality }\end{array}$} & \multicolumn{2}{|c|}{ Age } & \multicolumn{2}{|c|}{ Income } \\
\hline & $\mathbf{r}^{\mathrm{a}}$ & $\mathbf{p}$ & $\mathbf{r}_{\mathrm{s}}^{\mathrm{b}}$ & $\mathbf{p}$ \\
\hline Daily spiritual experiences & 0.030 & 0.447 & -0.003 & 0.948 \\
\hline Values/beliefs & -0.016 & 0.689 & 0.012 & 0.764 \\
\hline Forgiveness & 0.073 & 0.064 & -0.066 & 0.096 \\
\hline Particular religious practices & 0.050 & 0.203 & -0.069 & 0.081 \\
\hline Religious Overcoming & 0.026 & 0.517 & -0.010 & 0.807 \\
\hline Religious support & 0.009 & 0.821 & -0.044 & 0.262 \\
\hline Organizational religiosity & 0.139 & $<0.001$ & -0.027 & 0.496 \\
\hline $\begin{array}{l}\text { Global self-assessment of Religi- } \\
\text { osity/Spirituality }\end{array}$ & 0.104 & 0.008 & -0.041 & 0.306 \\
\hline
\end{tabular}

Regarding the variable age, a weak positive correlation was observed in the dimensions of organizational religiosity $(\mathrm{p}<0.001)$ and global self-assessment of religiosity/spirituality $(\mathrm{p}=0.008)$. There were no statistically significant differences between the areas of religiosity/spirituality and income.

\section{Discussion}

This study shows the cross section as a limitation that does not enable to establish a causal relationship.

Regarding the socio-demographic variables, the data in this study are consistent with the national and international literature, regarding female ${ }^{(1,6,11-13)}$, age group ${ }^{(1,12)}$, marital status ${ }^{(12-14)}$ and differing from education $^{(6,11,13)}$ and income $\mathrm{e}^{(13-14)}$.
As for religious/spiritual history, this dimension refers to the experiences that the individual had and what attributes religious/spiritual motivations. It should be emphasized that religious practices and beliefs can influence mental health, having an impact on emotional well-being and, consequently, providing resources and coping behaviors ${ }^{(13)}$. Research with the elderly emphasized that regular participation in masses, services, and religious meetings reflected benefits of social support ${ }^{(15)}$.

Faith and prayer bring about a sense of closeness to the sacred/divine for the protection and support of adverse situations ${ }^{(3)}$. The practice of prayer brings about the feeling of gratitude for the life that reflects in well-being and relaxation ${ }^{(15)}$. Being a dimension of human existence, spirituality and religiosity provide well-being, which can help in the adaptation and overcome of stressful events ${ }^{(3)}$. In this way, it is emphasized how much religion and spirituality are important in the lives of many elderly people.

As for commitment, this dimension is used to measure the level of religious involvement of the individual, as well as a commitment to one's religious belief ${ }^{(10)}$. A community study found that religious beliefs contribute decisively to well-being and have repercussions on physical and mental health throughout the aging process for older people $\mathrm{e}^{(7)}$.

This study did not investigate the monetary values of the contributions to the religious community, a finding also evidenced in another study, which mentions that in Brazil other types of donations (such as clothing and food) are very common. As a result, there would be no way to correlate this type of contribution with the financial one $\mathrm{e}^{(10)}$.

Regarding the weekly hours, a similar result was found in research with adults and the elderly, which showed that the time spent with religious or spiritual activities was 0-3 hours ${ }^{(10)}$.

Brazil has a great religious plurality, with a predominance of Catholicism, followed by Protestantism. This result was also evidenced in a national survey, in which $60.8 \%$ declared as Catholics and $19.9 \%$ as 
Evangelicals ${ }^{(5)}$. In international research, Catholicism was also identified as the most practiced religion (81.2\%), followed by Protestantism $(15.7 \%)^{(6)}$.

Regarding the elderly population and the relationship with religion in the third age, it should be pointed out that with the advent of retirement the elderly need to seek an expansion of their social networks, through clubs; associations; religious activities; travel groups, sports, cultural, leisure, volunteer, among others. Also, they should not be restricted only to the relationships of work/profession exercised throughout life ${ }^{(16)}$. In this way, the church is shown as one of the main sources of aid for the formation of these social networks, which favors the bond of the elderly with the religion.

As for the difference in the dimensions between the genders, it is important to emphasize that these dimensions evaluate the connection of the individual with a superior/divine power in daily life; religious values and beliefs; the degree to which individuals forgive others and the degree of belief in the forgiveness of a higher power; the frequency of religious behavior; strategies of religiosity and spirituality used to deal with difficult circumstances of life; and how much they realize that their religious communities provide help, support, and comfort ${ }^{(13)}$.

Women practice religion daily more and express spirituality, and this relationship intensifies throughout life and it has positive effects on the life and health of the practitioners ${ }^{(2)}$. This result was consistent with a survey conducted in two general hospitals with 656 adults and elderly, in which women presented higher averages in the dimensions of the Brief Multidimensional Religious/Spirituality Scale when compared to men ${ }^{(10)}$.

Likewise, women tend to attend more religious activities, a result consistent with national and international research with adults and the elderly ${ }^{(6,10)}$. The greater religious/spiritual involvement reflects positively on the aging process, causing a protective effect on life and its adversities, especially on women ${ }^{(2)}$.
Research of the documentary type points out that people who are adherents of a religion and/or who possess a considerable spirituality can more easily develop feelings of forgiveness as a coping strategy for situations that cause emotional distress ${ }^{(17)}$.

As for the correlation with age, the organizational religiosity dimension assesses the frequency of involvement in formal public religious institutions ${ }^{(13)}$. It is understood that the greater the age, the greater the religious participation in the churches and the greater the self-reference on how religious/spiritualized the individual is considered. A survey of 720 adults and the elderly found equivalent data, where the people 60 years old or more was significantly related to the practice of religion $(\mathrm{p}<0.001)$. The research also indicated that the higher the age group, the greater the practice of religion $^{(7)}$.

As regards the global self-assessment of religiosity/spirituality, this dimension assesses how religious/spiritual the individual considers himself/ herself ${ }^{(13)}$. Research with adults and the elderly emphasized that with the advancing age, religious beliefs represent an important source of emotional support with a significant impact on the mental and physical health of practitioners ${ }^{(7)}$. It is believed that with increasing age there is a greater relationship with God, which can result in positive spiritual development, reflecting a successful aging.

Finally, the crucial role of spirituality and religiosity in Nursing is emphasized, since they can provide a more active aging, a greater sense of life and help in adaptation in stressful situations and overcoming crises, such as loss, illness, pain and other types of suffering(6). Also, they can contribute to social support, emotional well-being and improved health and quality of life.

It is believed that the findings of this research can sensitize health professionals, in particular nurses, to value the benefits of spirituality and religiosity as strategies of care for the elderly, based on professional and ethical commitment. Nursing, through the 
holistic view, can strengthen care practices and health interventions by considering the spiritual and religious aspects to the better well-being of the elderly ${ }^{(6)}$, at all levels of care.

\section{Conclusion}

The elderly women presented higher averages in most dimensions of religiosity and spirituality. The older the person is, the greater the correlation in organizational religiosity and global self-assessment dimensions. The income did not present significant correlation with the dimensions of religiosity and spirituality.

\section{Acknowledgment}

The Foundation for Research Support of the State of Minas Gerais for financial support. Process number 02035-14.

\section{Collaborations}

Rodrigues LR, Nader ID, Melo e Silva AT, Tavares DMS and Molina NPFM contributed in the design and project, analysis and interpretation of data and article writing. Asunção LM contributed to the writing of the article. All authors contributed to the relevant critical review of intellectual content and final approval of the version to be published.

\section{References}

1. Instituto Brasileiro de Geografia e Estatística. Síntese de indicadores sociais - uma análise das condições de vida da população brasileira [Internet]. 2014 [citado 2016 set 20]. Disponível em:http://biblioteca.ibge.gov.br/visualizacao/ livros/liv91983.pdf

2. Manning LK. Enduring as lived experience: exploring the essence of spiritual resilience for women in late life. J Relig Health. 2014; 53(2):35262. doi: http://dx.doi.org/10.1007/s10943-0129633-6
3. Gutz L, Camargo, BV. Espiritualidade entre idosos mais velhos: um estudo de representações sociais. Rev Bras Geriatr Gerontol. 2013; 16(4):793804. doi: http://dx.doi.org/10.1590/S180998232013000400013

4. Koenig HG, King DE, Carson VB. Handbook of religion and health. New York: Oxford University Press; 2012.

5. Martinez EP, Alves AC, Carneiro AFTM, Jorge TM, Carvalho ACD, Zucoloto ML. Investigação das propriedades psicométricas do Duke Religious Index no âmbito da pesquisa em Saúde Coletiva. Cad Saúde Coletiva. 2014; 22(4):419-27. doi: http:// dx.doi.org/10.1590/1414-462X201400040016

6. Palência IPG, Banquett DC, Quintana MC, Villamizar AL, Mendoza YV. Spirituality and religiosity in elderly adults with chronic disease. Invest Educ Enferm. 2016; 34(2):235-42. doi: http://dx.doi. org/10.17533/udea.iee.v34n2a02

7. Zenevicz L, Madureira VS, Moriguchi Y. The religiosity in the process of living getting old. Rev Esc Enferm USP. 2013; 47(2):433-9. doi: http://dx. doi.org/10.1590/S0080-62342013000200023

8. Damiano RF, Costa LA, Viana MTSA, Moreira-Almeida A, Lucchetti ALG, Lucchetti G. Brazilian scientific articles on "spirituality, religion and health". Arch Clin Psychiatry. 2016; 43(1):11-6. doi:http://dx.doi.org/10.1590/010160830000000073 http://dx.doi.org/

9. Bertolucci PHF, Brucki SMD, Campacci SR, Juliano Y. O mini-exame do estado mental em uma população geral: impacto da escolaridade. Arq Neuropsiquiatr.1994;52(1):1-7.doi:http://dx.doi. org/10.1590/S0004-282X1994000100001

10. Curcio CS, Lucchetti G, Moreira-Almeida A. Validation of the portuguese version of the Brief Multidimensional Measure of Religiousness/Spirituality (BMMRS-P) in clinical and non-clinical samples. J Relig Health. 2015; 54(2):435-48. doi: http://dx. doi.org/10.1007/s10943-013-9803-1

11. Amaral FLJS, Guerra RO, Nascimento AFF, Maciel ACC. Apoio social e síndrome da fragilidade em idosos residentes na comunidade. Cien Saude Coletiva. 2013; 18(6):1835-46. doi: http://dx.doi. org/10.1590/S1413-81232013000600034 
12. Leite MT, Castioni D, Kirchner RM, Hildebrandt LM. Capacidad funcional y nivel cognitivo de adultos mayores residentes en una comunidad en el sur de Brasil. Enferm Glob [Internet]. 2015 [citado 2017 Jun 26];14(37):1-11. Disponible en: http://scielo.isciii.es/scielo.php?script=sci_arttext\&pid=S1695-61412015000100001\&lng=es

13. Johnstone B, Yoon DP, Cohen D, Schopp LH, McCormack G, Campbell J, et al. Relationships among spirituality, religious practices, personality factors, and health for five different faith traditions. J Relig Health. 2012; 51:1017-41. doi: http://dx.doi.org/10.1007/s10943-012-9615-8

14. Borges DT, Dalmolin BM. Depressão de idosos em uma comunidade assistida pela estratégia de saúde da família em Passo Fundo, RS. Rev Bras Med Fam Comunidade. 2012; 7(23):75-82. doi: http://dx.doi.org/10.5712/rbmfc7(23)381
15. Rocha ACAL, Ciosak AI. Chronic disease in the elderly: spirituality and coping. Rev Esc Enferm USP. 2014; 48(Esp2):92-8. doi: http://dx.doi. org/10.1590/S0080-623420140000800014

16. Araujo CK, Cardoso CMC, Moreira EP, Wegner E, Areosa SVC. Vínculos familiares e sociais nas relações dos idosos. Rev Jovens Pesquisadores [Internet]. 2012 [citado 2017 jul 19]; 1:97107. Disponível em: https://online.unisc.br/ seer/index.php/jovenspesquisadores/article/ view/2868/2033

17. Rocha IA, Sá ANP, Braga LAV, Ferreira Filha MO, Dias MD. Community integrative therapy: situations of emotional suffering and patients' coping strategies. Rev Gaúcha Enferm. 2013; 34(3):15562. doi: http://dx.doi.org/10.1590/S198314472013000300020 